\title{
COM QUANTAS CORES SE FAZ UMA DOCÊNCIA? DESVELANDO A HOMOFOBIA NO ESPAÇO ESCOLAR
}

\author{
¿CUÁNTOS COLORES CREAN UNA EXPERIENCIA DE ENSEÑANZA? \\ REVELANDO LA HOMOFOBIA EN EL ESPACIO ESCOLAR
}

\author{
HOW MANY COLORS BUILD A TEACHING EXPERIENCE? \\ CLARIFYING HOMOPHOBIA IN SCHOOL ENVIRONMENT
}

DOI: $10.22481 /$ rbba.v10i01.8826

Lara Costa Barreto

Universidade Estadual do Sudoeste da Bahia-Brasil

ID Lattes: http://lattes.cnpq.br/2352359359558569

ORCID: https://orcid.org/0000-0003-3524-3830

Endereço Eletrônico: larac-barreto@ yahoo.com.br

João Diógenes Ferreira dos Santos Universidade Estadual de Feira de Santana-Brasil ID Lattes: http://lattes.cnpq.br/6164576545378489

ORCID: https://orcid.org/0000-0001-5924-9773 Endereço Eletrônico: jdfsantos@uefs.br

\section{RESUMO}

Este trabalho teve como objetivo pesquisar a concepção e posicionamento pedagógico sobre a homofobia no cotidiano da escola, a partir das narrativas das/os docentes. Para tanto, foi utilizado o recurso da entrevista semiestruturada com dezessete professoras e professores de duas escolas públicas do município de Vitória da Conquista-Bahia-Brasil. Essas e esses docentes narraram sobre sua formação, seu posicionamento sobre a homofobia e a diversidade sexual. Dialogou-se com o conceito de homofobia, com a formação docente e naturalização da violência legitimada contra a população LGBTI. Os resultados apontaram que, a partir das narrativas das/os 
docentes, a falta de conhecimento em torno da diversidade sexual e gênero demonstra que os/as docentes não possuam instrumentos para intervir nos momentos de violência homofóbica no espaço escolar.

Palavras-Chave: Educação; Homofobia; Diversidade Sexual.

\section{RESUMEN}

Este trabajo tuvo el objetivo de investigar la concepción y el posicionamiento pedagógico sobre la homofobia en la vida cotidiana de la escuela, con base en las narrativas de los docentes. Para ello, fue utilizado el recurso de entrevista semiestructurada con diecisiete docentes de dos escuelas públicas de la ciudad de Vitória da Conquista, en Bahía, Brasil. Estas personas, profesionales de educación, hablaron sobre su formación, su posicionamiento sobre la homofobia y la diversidad sexual. Fue debatido el concepto de homofobia, la formación docente y la naturalización de la violencia legitimada contra la población LGBTI. Los resultados señalaron que, con base en las narrativas de los docentes, la falta de conocimiento sobre diversidad sexual y género demuestra que los docentes no tienen herramientas a disposición para intervenir en momentos de violencia homofóbica en el espacio escolar.

Palabras-clave: Educación; Homofobia; Diversidad sexual.

\section{ABSTRACT}

This work sought to analyze the pedagogical conception and positioning about homophobia in the school's daily life, based on the teachers' narratives. We used the semistructured interview with seventeen teachers from two public schools in the city of Vitória da Conquista in Bahia Brazil. These teachers narrated about their education, their position about homophobia and sexual diversity. We dialogued with the concept of homophobia, that in many ways have naturalize and legitimate violence against the LGBTI population. The results showed that, based on the teachers' narratives, the lack of knowledge about sexual and gender diversity demonstrates that the teachers do not have instruments to intervene in moments of homophobic violence in the school environment.

Keywords: Education; Homophobia; Sexual Diversity. 


\section{COM QUANTAS CORES SE FAZ UMA DOCÊNCIA? DESVELANDO A HOMOFOBIA NO ESPAÇO ESCOLAR}

\section{INTRODUÇÃO}

O debate em torno da homofobia ${ }^{\mathrm{i}}$ se faz urgente e necessário, pois na atual conjuntura há uma crescente onda de crimes relacionados à sexualidade. Há também outras expressões de violência que se manifestam por meio da discriminação das lésbicas, gays, bissexuais, travestis e transexuais. A homofobia, a lesbofobia e a transfobia são expressões dessa violência, anunciadas pelo ódio, pelo preconceito e pela repugnância contra a população LGBTI (Lésbicas, Gays, Bissexuais, Travestis, transexuais e Intersexuais) e, tais manifestações são representadas na mídia televisiva, impressa e nas redes sociais de uma forma banalizada.

As vulnerabilidades que são impostas por preconceitos e discriminações e que atingem a todas e todos por suas características pessoais, sejam elas de classe, gênero, raça/cor, orientação sexual, entre outros marcadores, fazem de cada um, um ser único e digno de respeito aos seus direitos. A população LGBTI é alvo de inúmeras violações de Direitos em muitas partes do mundo ${ }^{\text {ii }}$.

Mediante a essa realidade de violência contra pessoas LGBTI, tanto no espaço escolar quanto na sociedade em geral, o presente estudo teve como objetivo geral pesquisar qual a concepção e posicionamento pedagógico das/os professoras/es, de duas escolas em Vitória da Conquista-Ba, em relação à homofobia, gênero e diversidade sexual no contexto escolar.

\section{CAMINHO METODOLÓGICO}

Utilizamos o recurso metodológico, a entrevista semiestruturada. A pesquisadora, com um roteiro previamente elaborado, realizou um diálogo com as/os entrevistadas/os, dando margem a estes sujeitos de narrar sua realidade.

As escolas selecionadas são de ensino médio - ensino médio regular e ensino médio e profissionalizante. Foram entrevistadas/os dezessete docentes, sendo quinze professoras/es e dois diretores, nas respectivas escolas. Dos 17 entrevistados, foram 8 homens e 9 mulheres. Para preservar as identidades das professoras e dos professores entrevistados VIRG foram ocultados os seus nomes e dos referidos espaços escolares. Para identificar os sujeitos desta pesquisa, optou-se em atribuir-lhes as letras do alfabeto.

É importante salientar que algumas professoras e alguns professores se recusaram a conversar e/ou serem entrevistadas/os. As duas instituições possuem 72 docentes - 45 mulheres e 27 homens - e 1965 discentes no total. 


\section{COMPREENDENDO GÊNERO E HOMOFOBIA}

É comum, ao se referir sobre gênero, associá-lo ao conceito de sexo, como se ambos tivessem o mesmo significado. Contudo, a categoria sexo está situada no campo da biologia e a de gênero no campo cultural. Neste trabalho, considerar-se-á, assim como Saffiotti (2004, p. 109), que "sexo e gênero seja considerada uma unidade, uma vez que não existe uma sexualidade biológica independente do contexto social em que é exercida."

Ao se compreender o gênero como uma construção social e não biológica, é necessário refletir sobre a categoria sexualidade. Segundo Louro, "muitos consideram que a sexualidade é algo que possuímos naturalmente [...] se ancorando na concepção que seria algo dado pela natureza." (2015, p. 11). Nesta mesma linha, a autora afirma que a "sexualidade envolve rituais, linguagens, fantasias, representações, símbolos, convenções [...]. Através de processos culturais, definimos o que é ou não natural. (LOURO, 2015, p. 11).

Assim, os corpos ganham sentido socialmente. A inscrição de gênero masculino e feminino nos corpos é feita no contexto de uma determinada cultura. De acordo com Louro (2015, p. 12), “as possibilidades da sexualidade - formas de expressar desejos e prazeres também são sempre socialmente estabelecidas e codificadas".

A sexualidade, de acordo com Foucault (1993), é um "dispositivo histórico", ou seja, é uma invenção social, uma vez que se constitui, historicamente, a partir de múltiplos discursos sobre o sexo: discursos que regulam, normatizam, instauram saberes, que produzem "verdades". Portanto, esse dispositivo opera como uma forma de generalizar e naturalizar a sexualidade e funciona como referência para todos os sujeitos. É por isso que a heterossexualidade é concebida como "natural" e também como universal e "normal".

Já o gênero, é uma categoria analítica que explica o conjunto de atribuições culturais e sociais postas aos indivíduos de diferentes sexos. Este tipo de teorização rejeita a explicação biológica do que é ser homem e ser mulher. Segundo Joan Scott (1995, p. 75):

o termo gênero [...] é utilizado para designar relações sociais entre os sexos. Seu uso rejeita explicações biológicas, como aquelas que encontram um denominador comum. Em vez disso, o termo gênero torna-se uma forma de indicar construções culturais - a criação social de ideias sobre os papéis adequados aos homens e às mulheres. 


\section{COM QUANTAS CORES SE FAZ UMA DOCÊNCIA? DESVELANDO A HOMOFOBIA NO ESPAÇO ESCOLAR}

Assim, gênero é uma construção social e, como tal, é passível de ser transformada. Para Butler, ser homem ou ser mulher não é algo fixo ou determinante por seu sexo biológico. De acordo com a autora:

Se alguém é uma mulher, isso certamente não é tudo que esse alguém é; o termo não logra ser exaustivo [...] nem sempre se constitui de maneira coerente ou consistente nos diferentes contextos históricos, e porque o gênero estabelece interseções com modalidades raciais, classistas." (BUTLER, 2003, p. 20).

Portanto, para a autora, "o gênero é culturalmente construído (grifo nosso)" (BUTLER, 2003, p. 24). Tem-se a impressão de que o gênero possui como característica ser fixo, imutável, mas é o contrário, apresentando a fluidez dessa categoria tecida socialmente, portanto, passível de mudança.

Outra autora que aborda o tema é Saffioti (1997). Ela enfatiza que a conceituação do termo gênero como uma construção social, ou seja, estudar gênero é analisar a formação de mecanismos sociais a qual são designados comportamentos referentes ao feminino e ao masculino.

A autora estabelece a distinção do conceito de gênero e sexo. O conceito de sexo tem o caráter biológico, distinguindo entre macho e fêmea. Segundo Saffiotti (1997), as sociedades humanas são construídas em várias gramáticas (conjunto de regras) para reger o "comportamento de homens e de mulheres, de brancos e negros, de ricos e de pobres, de crianças, adultos e velhos, das pessoas consideradas normais e loucas" (1997, p. 40). De acordo com a autora, os caminhos que perpassam a questão de gênero nos fazem pensar que a sociedade está amparada em três pilares: classe, sexo/gênero e raça/etnia. Para Saffiotti (1997, p. 41), há uma regulação de condutas socialmente aceitáveis quanto ao sexo, definindo "o que é ser homem e o que ser mulher."

Saffiotti (1997) analisa que a categoria histórica de gênero não constitui uma camisa de força, não prescrevendo, assim, um destino imutável. É lógico que o gênero traz em si um destino. Entretanto, cada ser humano - homem ou mulher - desfruta de certa liberdade para escolher sua trajetória. O gênero, assim, apresenta um caráter determinante, mas deixando sempre espaço para o imponderável, um grau variável de liberdade de opção, com determinada margem de manobra.

A autora aborda como essa rigidez da categoria gênero pode construir a violência de gênero, fazendo um comparativo sobre "como são palpáveis as diferentes formas de violência 


\section{COM QUANTAS CORES SE FAZ UMA DOCÊNCIA? DESVELANDO A HOMOFOBIA NO ESPAÇO ESCOLAR}

em relação às meninas e aos meninos, assim como para com brancos e negros" (SAFFIOTTI, 2004, p. 82)

A violência de gênero é o conceito mais amplo, abrangendo vítimas como mulheres, crianças e adolescentes de ambos os sexos. Essa violência se ancora no exercício do patriarcado, há uma hierarquia pré-estabelecida. De acordo com Saffiotti (1994, p. 444), "os homens detêm o poder de determinar a conduta das categorias sociais nomeadas, recebendo autorização ou, pelo menos, tolerância para punir o que lhes apresente como desvio.”

A discussão trazida por Saffiotti (2004, p. 45) sobre patriarcado é relevante, pois como outros fenômenos sociais, também "o patriarcado está em permanente transformação". No patriarcado, segundo Saffiotti (2004, p. 118), "as relações são hierarquizadas entre seres socialmente desiguais, enquanto o gênero compreende também relações igualitárias”. Assim, para a autora, o patriarcado é um caso específico de relações de gênero.

Saffiotti (2004) lembra que em uma sociedade patriarcal, existe uma forte banalização da violência, de forma que há uma tolerância e até certo incentivo da sociedade para que os homens possam exercer sua virilidade baseada na força/dominação com fulcro na organização social de gênero.

São importantes as reflexões em torno da categoria patriarcado visto que é fundamental nomear a dominação-exploração e não naturalizar o domínio dos homens. Na sociedade atual, são construídas as imagens do masculino e do feminino e, assim, os indivíduos teriam padrões para se adequar, a partir do seu sexo biológico - masculino para meninos e feminino para meninas.

No espaço escolar, pode ser percebida essa organização social de gênero, com relações desiguais entre homens e mulheres. E, nessa linha de pensamento, aquelas/es que se encontram fora dos padrões erigidos pela heteronormatividade enfrentam, em seus cotidianos, várias manifestações de violência que vão desde a uma simples brincadeira, expressa em piadas, à destruição e ao o silenciamento do corpo e da sexualidade, até a morte.

Segundo Marinho e Santos (2012, p. 12), há "um modelo societário em que o "normal" é ser homem, branco, heterossexual, ocidental, oriundo das classes dominantes, provedor, viril e forte". É como se os papéis masculinos e femininos fossem estabelecidos naturalmente. Homens e mulheres devem se relacionar dentro de um padrão heterossexual, em que a mulher se encontra em condição inferior. 


\section{COM QUANTAS CORES SE FAZ UMA DOCÊNCIA? DESVELANDO A HOMOFOBIA NO ESPAÇO ESCOLAR}

Para esses autores, a heteronormatividade "impõe a opressão, o silenciamento da orientação sexual, a submissão e a invisibilidade da mulher frente ao homem, compondo uma sociedade sexista.” (MARINHO e SANTOS, 2012, p. 08).

São diferentes situações de discriminação, preconceito, agressões físicas e psicológicas, muitas delas realizadas por pessoas conhecidas, inclusive na escola. Essa conduta marca violentamente a trajetória dessas pessoas que, além de sofrerem com a segregação e a vigilância sobre seus comportamentos sexuais, ainda são, em não raras ocasiões, ironicamente questionadas sobre sua orientação sexual.

De acordo com a UNESCO (2000, p. 128), “a escola pública brasileira vive hoje o desafio de aceitar os "diferentes", aqueles desde sempre ausentes do espaço escolar, ou que nele estiveram apenas por breves passagens, sendo logo excluídos”. São diferenças de raça, etnia, classe e econômica, orientação sexual, gênero, organização familiar, pertencimento religioso, diferenças físicas em termos de possibilidades do corpo (cadeirantes, alunos com deficiências físicas como a surdez), diferenças de geração (alunos mais jovens e alunos mais velhos misturados na mesma turma), e muitas outras.

$\mathrm{Na}$ escola, por ser um lugar de aprendizagens, a/o professora/o deve conduzir sua relação com as/os discentes no sentido de explorar as possibilidades dessas aprendizagens. A inclusão dos/das discentes LGBTI exige uma transformação da estrutura escolar.

Não é possível educar num ambiente de falta de respeito, e a agressão - verbal e até mesmo física - tem sido uma arma de expulsão de indivíduos que não se enquadram na regra da heteronormatividade. É necessário construir um ambiente de respeito e aceitação, o que não significa permitir que todos os desejos dos alunos em relação à vida amorosa e particularmente sexual sejam admitidos na escola. (UNESCO, 2009, p. 132).

O debate sobre a diversidade sexual na escola pode possibilitar um processo de aprendizagem que visa romper com o binarismo certo-errado, proibido-permitido (LOURO, 2015). A importância do diálogo e da informação aos jovens no ambiente escolar se dá pelo fato de ser uma população vulnerável a esse tipo de violência. Segundo o Relatório de Violência Homofóbica no Brasil de 2013 (2016) ${ }^{\mathrm{iii}}$, “a grande maioria das vítimas se concentra nesta população, com 54,9\% de vítimas estão entre 15 e 30 anos. Em 2012, a população entre 15 e 29 anos foi a grande maioria dos infringidos pela violência homofóbica, somando $61,16 \%$. 


\section{COM QUANTAS CORES SE FAZ UMA DOCÊNCIA? DESVELANDO A HOMOFOBIA NO ESPAÇO ESCOLAR}

Portanto, criar canais que possibilitem a discussão desmistificando o que está envolta a este tema, é uma maneira de empoderar os jovens estudantes que vivenciam a homofobia na juventude. iv

\section{FORMAÇÃO DOCENTE}

As pesquisas em torno dos saberes docentes são vastas. Utilizando a concepção de Bombassaro (1992, p. 35) sobre a expressão "saber” (apud CUNHA, 2007, p. 30), compreendese que é o mesmo que "dominar uma técnica, poder manusear, remetendo ao mundo prático que além de ser condição, possibilidade de qualquer noção é, também, o lugar efetivo onde a noção pode ser produzida."

O saber profissional que norteia a atividade da/o professar/o se insere na multiplicidade própria do trabalho dos profissionais que atuam em diferentes situações e que, portanto, precisam agir de forma diferenciada, mobilizando diferentes teorias, metodologias, habilidades.

As/os docentes nas narrativas abaixo alegam não saberem lidar com situações de preconceito ou discriminação em sala quando se trata de discentes LGBTI:

Professor $\mathrm{H}$ :

Olha formação não há, principalmente aqui. Onde você tem muita gente que não passou ou pelo menos não cursou uma disciplina desta na faculdade, como essa galera bacharel (formação bacharelado), como eu, então nunca tivemos nenhuma formação pra lidar com isso, mas sinceramente, o bom senso, às vezes ajuda muito, às vezes você tem a formação, mas não tem uma cabeça boa.

Professor G:

Essas discussões puxadas pela academia, pelo menos do contexto do curso que fiz (história, ano 2000) não tem nada haver.

Professor L:

No meu período foi totalmente ausente, a discussão não se fazia dentro da academia. Meu processo formativo foi em uma sala que a gente começou em 40 [quarentas] estudantes e terminamos em 13 [treze]. Desses 13 [treze] estudantes, pelo menos 5 [cinco] eram homossexuais, e mesmo assim, não havia uma discussão, embora fosse natural, em nosso meio, mas ninguém tocava no assunto. Era quase como se fosse uma cisma né?

O desenvolvimento de uma docência que reproduza práticas homofóbicas está relacionado a um despreparo em sua formação como muitas e muitos alegaram nas narrativas. Segundo Emannuel Cunha (2007, p. 33), o “saber profissional dos professores é constituído não por um saber específico, mas por vários saberes de diferentes matizes, origens, aí incluídos 
também, o saber-fazer e o saber da experiência”. Desse modo, os saberes das/os professoras/es também irão ser reconstruídos no dia a dia da sala de aula, a partir das experiências com suas/seus discentes bem como do contínuo do seu desenvolvimento profissional.

Contudo, ainda há uma grande lacuna nas questões relacionadas à diversidade sexual e ao gênero durante a formação docente. Nas narrativas das/dos docentes, observa-se como isso reflete no dia a dia em sala de aula.

Professor D:

[...]Várias vezes, presenciei situações de preconceito. Tive que parar a aula, intervir, provocar uma discussão. Isso continua acontecendo, sempre ocorre. Desde quando comecei a ensinar sempre existiu, mas antes a gente fingia que não existia, a gente passava por cima dele. Quando surgia alguma questão assim, você desconversava. Eu como aluno, presenciei várias vezes isso na sala, e sempre foi uma coisa muito incômoda, e na atualidade, como é um tema que tem aparecido nas discussões mais amplas na sociedade, sobretudo, havendo essa preocupação dentro da legislação, começa a ter um espaço de resistência a isso, que antes você não dispunha desse espaço e nem uma garantia legal pra resistir a este tipo de processo discriminatório. [grifo nosso]

Já o Professor L:

[...] dentro do curso de História tem estrutura e fundamento do ensino [pausa] e trabalhamos algumas coisas. Agora, não há um aprofundamento. São muitas leis, leis, leis e sem aprofundamento teórico. Em didática, a gente tem algumas coisas, aí discute um pouco mais. E vai também muito do professor. Porque não é o que está na ementa, mas muito do que pensa o professor.

O preconceito e a discriminação às/os alunas/os LGBTI, por parte das/os docentes, muitas vezes, se devem por desconhecimento em relação ao tema, talvez nunca tiveram a oportunidade de sair do senso comum e aprofundar em discussões teóricas, sobre diversidade sexual e gênero. O Professor D ainda relata que como ele percebe as conversas na sala das/os professoras/es:

A sala dos professores é um retrato da sociedade. Você tem pessoas que são abertas, e você tem pessoas que são extremamente preconceituosas. Isso, inclusive, constitui um problema seríssimo do processo formativo dos futuros professores. É uma questão a se discutir no espaço de formação desses professores. Você percebe comentários que, às vezes por parte de professores, algo altamente discriminatório, preconceituoso, sexista, e todos os 'ismos' que a gente pode colocar.

Em alguns casos, esse processo de preconceito e/ou discriminação, por parte das/os docentes, pode existir pelo fato de serem de gerações onde a sexualidade era um tema proibido de se discutir em quaisquer espaços. A Professora E afirma: 


\section{COM QUANTAS CORES SE FAZ UMA DOCÊNCIA? DESVELANDO A HOMOFOBIA NO ESPAÇO ESCOLAR}

Eu acho que a maioria das pessoas que tem essa dificuldade [em aceitar], é porque são como eu, mais velhas. As pessoas jovens, hoje, não têm mais assim, restrição, com relação a isso (homossexualidade). Um ou outro você vê assim, certo sarcasmo com o assunto, mas a grande maioria hoje não discute isso como sendo um problema de relacionamento entre eles. As meninas se dão muito bem com eles (gays) e os meninos também se dão bem com eles. E se o aluno, como te falei, é um aluno que mobiliza que agrega, ele conquista todo mundo, a escola toda é contagiada. (Professora $\mathrm{E}^{v}$ )

A grande maioria das/dos docentes entrevistadas/os não tinham conhecimento acerca do Plano Nacional de Educação- PNE ou, quando sabiam da existência do mesmo, era de forma superficial. Foi possível perceber a carência de debates e discussões sobre a diversidade sexual nas escolas a partir das narrativas das/os docentes entrevistadas/os sobre situações que presenciaram durante as aulas.

\section{Professor C:}

Muitos alunos se assumem. Na verdade, se assumem verbalizando. Eu já tive alunos [gays]. Eles tinham comportamentos de homossexuais, mas eles não se assumem, não se percebiam assim. Então, assim, é complicado. Eu tenho um aluno que é criticado pelos colegas e às vezes ele nem entende o motivo, porque como eu trabalhei com ensino fundamental, eu tinha um aluno que tinha todo um comportamento, mas ele não entendia o que estava acontecendo, pela idade, por ser muito novo, então assim, é complicado, você trabalhar isso na sala de ensino fundamental, principalmente dentro de escola particular, tem uma série de cobranças né?! E que vai além da sala de aula e muitas vezes a gente não tem abertura para [pausa] os alunos estão ainda muito naquela forma de homem e coisa de mulher. [grifo meu]

Professor G:

Eles agiam dizendo que era brincadeira, sempre no tom de brincadeira. Mas o aluno que era alvo você sente que ele fica constrangido e os outros tentavam dissipar o fato de eu ter chamado à atenção.

Professor H:

Não tem nada que me chama a atenção assim. Nunca teve nenhuma brincadeira, ofensa com relação a eles. Tem, como falei, esses dois grupos, $o$ grupo que entra na sala como um aluno normal, como homem e uma mulher, mas há também aqueles que entram já pulando. Mas eu nunca vi nada em minhas aulas de preconceito. [grifo meu]

Professora I:

Sempre tem situações em sala que surge uma brincadeira, eles colocam apelidos. Às vezes quando vejo que algum aluno se ofendeu eu paro a aula e chamo a atenção do aluno, mas vejo que isso é comum em sala, e às vezes deixo passar, eles acabam resolvendo entre eles. (Professora ${ }^{\mathrm{vi}}$ ) 


\section{COM QUANTAS CORES SE FAZ UMA DOCÊNCIA? DESVELANDO A HOMOFOBIA NO ESPAÇO ESCOLAR}

Professora J:

É comum, e de uns tempos pra cá é mais comum ainda. Acho que logo quando eu comecei a lecionar eu não percebia esse tipo de comportamento. Mas agora não. Que está tudo mais liberal, tudo está mais na mídia então eles não têm mais aquele preconceito, eu não percebo preconceito em falar sobre isso. Então, sempre tem aquela piadinha, aquela brincadeira [relacionada à sexualidade]. (grifo nosso. Professora $\mathbf{J}^{\mathrm{vii}}$ )

Observa-se pelas narrativas a dificuldade em situações cotidianas que envolvem as "brincadeiras em relação às/aos discentes LGBTI. O Professor H destaca a palavra "normal" para descrever as/os discentes heterossexuais. Existe essa construção de "normalidade", e a homofobia, mesmo que muitas vezes velada, é uma ação da defesa dessa normalidade projetada socialmente.

A preocupação por estar sempre reafirmando a normalização da heterossexualidade, como afirma Deborah Britzman (1996, p. 80) "normalizante", pode ser uma constante em na escola. De acordo com a autora, "se a normalização tem como referência a heterossexualidade e coloca a homossexualidade e o sujeito homossexual como desviantes, precisamos nos perguntar de que modo isso se "faz" nas escolas". Nas narrativas, podemos constatar que as/os docentes parecem ter certo receio de que a "mera menção da homossexualidade vá encorajar práticas homossexuais e vá fazer com que os/as jovens se juntem às comunidades gays e lésbicas". (BRITZMAN, 1996, p. 137).

O Professor C destaca que:

É delicado tratar desses temas. A própria direção não tem preparo. Às vezes, a gente não sabe como fazer para socializar aquela criança com os outros colegas né?! E aqui [na escola que leciona] os alunos que se assumiram ou que já verbalizaram isso, eu não percebo que eles têm repressão dos colegas E acho que isso é importante porque independente de sua sexualidade, você é uma pessoa como outra qualquer.

Já a Professora D:

Hoje é comum, no espaço de sala de aula [ter alunos gays]. Inclusive muito jovens ainda, tem situações de adolescentes ainda, na faixa de 12, 13, 14 anos, já se assumindo. Então, isso é uma situação nova, e é uma situação que eu percebo que em 4, 5 anos ela avançou muito. A presença das pessoas que se assumiam nos espaços públicos era muito mais restrita, justamente por conta de processo cultural de longas décadas, centenas de anos que sempre foram discriminados, excluídos, rejeitados. E ultimamente, muitos têm percebido que podem romper essa barreira. Se sentem mais à vontade, eu acho que há uma abertura na sociedade, apesar de haver muita discriminação, eu acho que nos últimos 10 anos tiveram avanços significativos nesse campo. 


\section{COM QUANTAS CORES SE FAZ UMA DOCÊNCIA? DESVELANDO A HOMOFOBIA NO ESPAÇO ESCOLAR}

A professora $\mathrm{D}$, ao narrar que muito jovens, na faixa de 12 a 14 anos, estão assumindo a homossexualidade, demonstra o desconforto de jovens nessa faixa etária revelarem sua orientação sexual fora do padrão estabelecido, como se houvesse uma determinação cronológica para o sujeito social ter a liberdade de exercer sua sexualidade.

As discussões acerca desses conteúdos são relevantes na formação inicial e continuada das/dos docentes, onde se possa questionar, segundo Louro:

[...] o binarismo rígido das relações de gênero, [...] com um olhar mais aberto, de uma problematização mais ampla (e também mais complexa), uma problematização que terá de lidar, necessariamente, com as múltiplas e complicadas combinações de gênero, sexualidade, classe, raça, etnia. (1997, p. 64)

De acordo com Louro (1997, p. 81) "Não há dúvidas de que o que está sendo proposto, objetiva e explicitamente, pela instituição escolar, é a constituição de sujeitos masculinos e femininos heterossexuais - nos padrões da sociedade em que a escola se inscreve." A escola opera, assim, na produção das sexualidades de meninos e meninas.

Para que possamos pensar em qualquer estratégia de intervenção é necessário, sem dúvida, reconhecer as formas de instituição das desigualdades sociais, bem como as limitações nas formações das/os docentes.

\section{PROFESSORAS/PROFESSORES E HOMOFOBIA}

Destacamos algumas narrativas de relatos sobre as dificuldades das/os docentes ao definir o conceito de homofobia. Eles e elas chegam a expressar a falta desses conteúdos em sua formação. Observamos também que mesmo não se dizendo preconceituosas/os, acabam adotando termos como "normal" para fazer a comparação das/os discentes que categorizam como sendo gays ou lésbicas.

Professora B:

Homofobia é um [pausa] fobia vem de medo, de repulsa. Medo, repulsa ao próprio sexo né? Eu sou totalmente contra, assim, a homofobia.

Professora C:

Eu acho que toda e qualquer forma de preconceito contra a sexualidade do outro. Eu não sei se minha definição é correta, mas é da forma que eu vejo. Eu acho que a gente tem que aprender a respeitar a individualidade do outro, enquanto pessoa sabe? Porque o que você faz entre quatro paredes só diz 


\section{COM QUANTAS CORES SE FAZ UMA DOCÊNCIA? DESVELANDO A HOMOFOBIA NO ESPAÇO ESCOLAR}

respeito a você. A gente tem que respeitar as pessoas como seres humanos que somos.

Professora D:

Qualquer processo de discriminação ou rejeição à opção sexual do outro, eu caracterizo homofobia como qualquer atitude desse tipo.

Professor H:

Olha eu não tenho uma posição sobre isso, não tive formação sobre isso. Eu acho que é a aversão ao outro, ao seu semelhante, e tal, qualquer tipo de relacionamento entre seu semelhante, mas eu não tenho uma discussão sobre isso assim.

Professora J:

[pausa] Eu acho que... sem necessidade disso. Eu acho estranho alguém falar que é homofóbico, acho assim que é uma coisa fora da realidade de hoje. Há anos atrás, quando tudo isso aí, era uma coisa restrita, escondida, a gente ouvia falar, ficava surpreso, mas hoje assim, a mídia está aí, explorando tanto isso aí...é uma coisa tão comum que acho que a gente sente assim, ouve falar: poxa como pode? Mas eu quando eu vejo alguém falar que é homofóbico, isso ou aquilo, e que fala um monte de coisa, eu acho um absurdo né? A pessoa não querer aceitar o que já é.

As narrativas acima demonstram como, em alguns casos, a/o docente tem dificuldade em conceituar a homofobia. De acordo com Louro (2015, p. 15), as sociedades "constroem os contornos demarcadores das fronteiras entre aqueles que representam a norma - que estão em consonância com seus padrões culturais - e aqueles que ficam fora dela, às suas margens". Compreende-se que, na nossa sociedade, a norma estabelecida tem como referência o sujeito masculino, heterossexual, branco, saudável, burguês e cristão. Assim, aqueles/as que não se enquadram nesses atributos, são nomeados de diferentes.

Para Butler (2002, p. 334), a homofobia "opera por meio da atribuição de um gênero prejudicado, defeituoso, falho, abjeto às pessoas homossexuais". Nesta linha, a heterossexualidade é o marco regulador da sexualidade, sendo controlada mediante a vigilância de gênero, onde os sujeitos que violam as normas de gêneros vivenciam humilhações e uma espécie de terror. (BUTLER, 2002)

Portanto, essas normas parecem exercer uma força, "fazendo com que o sexismo e a homofobia se configurem como componentes do regime binário das sexualidades, de modo que acaba por aí se converter em uma guardiã das fronteiras sexuais (hetero/homo) e das de gênero (masculino/feminino)".

Nessa perspectiva, a noção de homofobia pode ser estendida para também atribuir a situações de preconceito, discriminação e violência contra qualquer pessoas -homossexuais ou 
não - cujas performances ${ }^{\text {viii }}$ e/ou expressões de gênero - interesses, atitudes, etc. - não se enquadram nos modelos hegemônicos - heterossexuais - impostos.

A escola, segundo Silva e Lastória (2019, p. 291), "tem a responsabilidade de desenvolver ações educativas que levem à formação ética para a construção de valores que respeitem a diversidade e aos direitos humanos". Incluir a diversidade sexual no currículo ainda se revela algo limitado devido aos valores da família tradicional, principalmente aquelas integrantes de grupos religiosos, hoje representados pela atual bancada evangélica no Congresso Nacional

Para Junqueira (2009, p. 395), uma sociedade "dotada de um projeto democrático tem a ganhar com a garantia da inclusão de todos os seus indivíduos e grupos, com o reconhecimento de suas diferenças e com a incorporação -e não a normalização- das temáticas que a diversidade suscita".

Compreende-se, assim, a importância de a diversidade estar presente tanto na formação docente como também dentro do currículo escolar, com discussões sobre o combate da desigualdade de gênero e todas as formas de preconceito e discriminação, "a fim de tornar a escola um espaço estratégico para a formação cidadã e a transformação social.” (JUNQUEIRA, 2009, p. 161).

\section{CONSIDERAÇÕES FINAIS}

Com a crescente violência homofóbica e sua naturalização, pessoas LGBTI e a sociedade como um todo, sofrem em silêncio com as piadas, agressões, por uma série de situações cotidianas que impõe a vigilância para que todas e todos manifestem apenas a heterossexualidade.

Os resultados apontam, a partir das narrativas das/os docentes, que a falta de conhecimento em torno da diversidade sexual, gênero, étnico-racial faz com que os/as docentes não possam intervir nos momentos de violência homofóbica no espaço escolar. As práticas docentes dos sujeitos perpassam pela formação inicial, continuada quando há, e pela sua visão de mundo. As/os docentes entrevistadas/os evidenciaram a dificuldade em abordar temas que envolvam sexualidade, homofobia, seja por não conhecer essas temáticas ou por sua convicção religiosa e política. Também se observa que ainda há dificuldades em se tratar sobre esses conteúdos, quando algumas e alguns docentes não demostraram, durante as entrevistas, estarem abertos ao diálogo. 


\section{COM QUANTAS CORES SE FAZ UMA DOCÊNCIA? DESVELANDO A HOMOFOBIA NO ESPAÇO ESCOLAR}

É preciso que haja discussões sobre a relação de gênero e a orientação sexual no espaço escolar, podendo ser um caminho para que esse modelo de opressão contra pessoas LGBTI não seja mais tratado com normal. A violência chega ao seu extremo, por meio de torturas, assassinatos por apenas possuírem uma sexualidade que não se enquadra na heteronormatividade.

O Brasil é um dos países que mais matam pessoas LGBTI (Relatório 2016 GGB, $\left.2017^{\mathrm{ix}}\right)$. Neste sentido, as educadoras e os educadores precisaram contribuir para que essas formas de violência não sejam banalizadas e naturalizadas, levando as/os educandos/educandas a um pensamento mais crítico e humanizado em relação às diferenças no espaço escolar, sempre levantando o debate e desconstruindo ideia de que a heterossexualidade é natural, superior e moralmente aceita.

Nas narrativas das/dos docentes, analisou-se que termos como "normal", "não tem jeito de gay", "era brincadeira", "foi só uma piada" são comuns no cotidiano escolar. Tais expressões tentam escamotear a homofobia na escola. Vale ressaltar o papel da/o educadora/o no combate da homofobia na escola, quando recorrem às práticas pedagógicas que abarquem a pluralidade e a diversidade.

Neste sentido, reconhece-se a importância de futuras pesquisas para que possam abordar sobre a homofobia, diversidade sexual, orientação sexual, gênero na escola e que se possa desconstruir os preconceitos e as discriminações contra pessoas LGBTI.

\section{REFERÊNCIAS}

BENTO, Berenice. Performances de gênero e sexualidade na experiência transexual. In LOPES, Denílson et al (org.). Imagem e diversidade sexual: estudos da homocultura. São Paulo: Nojosa, 2004.

BRASIL. Ministério da Saúde. Brasil sem Homofobia: programa de combate à violência e discriminação contra GLTB e de promoção da cidadania homossexual. - 2a . ed. Brasília: Câmara dos Deputados, coordenação de publicações, 2004.

BRITZMAN, Deborah. O que é essa coisa chamada amor: identidade homossexual, educação e currículo. Educação e realidade. Porto Alegre, v. 21, p. 71-96, jan./jun. 1996. Disponível em: $<$ https://seer.ufrgs.br/educacaoerealidade/article/view/71644>. Acessado em: 27 maio 2021.

BOMBASSARO, Luiz Carlos. As Fronteiras da epistemologia: como se produz o conhecimento. $-2^{\text {a }}$ ed. Petrópolis: Vozes, 1992. 
BUTLER, Judith. Cuerpos que importam. Sobre los limites materiales y discursivos del sexo. Buenos Aires: Paidós, 2002. Disponível em: $<$ https://reddesalud.org/apc-aafiles/1342d291dfef7a4d531a2a778bc9da8e/butler-judith-cuerpos-que-importan.pdf>. Acessado em: 27 maio 2021.

BUTLER, Judith. Problemas de Gênero: feminismo e subversão da identidade. Tradução de Renato Aguiar. - Rio de janeiro: Civilização brasileira, 2003.

CUNHA, Emmanuel Ribeiro. Os Saberes Docentes ou Saberes dos Professores. Revista COCAR, v. 1 n. 2 Jul/Dez 2007. Disponível em:< https://periodicos.uepa.br/index.php/ cocar/article/view/130>. Acessado em: 26 maio 2021

FOUCAULT, Michael. Microfísica do poder. Organização e tradução de Roberto Machado. Rio de Janeiro: Edições Graal, 1979.

FOUCAULT, Michael. História da Sexualidade. Vol. 1: A vontade de saber. Trad. Maria T. da C. Albuquerque e J. A. Guilhon Albuquerque. 11 ed. Rio de Janeiro, Graal. (1999), História, 1993.

HARTMANN, Heidi (1979) The Unhappy Marriage of Marxism and Feminism: Towards a More progressive Union, Capital and Class. n.8, p. 1-33. Disponível em: $<$ https://edisciplinas.usp.br/pluginfile.php/4079326/mod_resource/content/1/Heidi\%20Hartma nn\%20unhappy\%20marriage\%201979.pdf >. Acessado em: 18 mar. 2021

JUNQUEIRA, Rogério Diniz (org.) Diversidade Sexual na Educação: problematizações sobre a homofobia nas escolas. - Brasília: Ministério da Educação, Secretaria de Educação Continuada, Alfabetização e Diversidade, UNESCO, 2009.

KENNEDY, N. Crianças Transgênero: mais do que um desafio teórico. Revista Cronos, v. 11, n. 2, 28 nov. 2010. Disponível em:

<https://periodicos.ufrn.br/cronos/article/view/2151/pdf>. Acessado em: 18 maio 2021.

LOURO. Guacira Lopes (org.). O CORPO EDUCADO Pedagogias da sexualidade. Guacira Lopes Louro, Jeffrey Weeks, Deborah Britzman, bell hooks, Richard Parker, Judith Butler Traduções: Tomaz Tadeu da Silva 2a Edição Autêntica Belo Horizonte, 2015.

LOURO. Guacira Lopes. Heteronormatividade e homofobia. In: JUNQUEIRA, R. D. (Org.). Diversidade sexual na educação: problematizações sobre homofobia nas escolas. Brasília: Ministério da Educação/UNESCO, 2009. v. 32. p. 85-93.

MARINHO, Marcos Silva e SANTOS, João Diógenes F. Heteronormatividade e Homofobia nos espaços educacionais de Vitória da Conquista/BA. Disponível em: $<$ https://www.yumpu.com/pt/document/read/12491040/12-heteronormatividade-e-homofobianos-espacos-escolares-uesb>. Acesso em: 02 fev. 2021.

NOBERT, Elias. Introdução. Ensaio teórico sobre as relações estabelecidos-outsiders. In:__ELIAS, Norbert \& SCOTSON, John L. Os estabelecidos e os outsiders. Rio de Janeiro: Jorge Zahar, 2000. 
PIMENTA, Selma. Formação de professores: identidade e saberes da docência. In:____Saberes pedagógicos e atividade docente. - São Paulo: Cortez, 1999.

Pesquisa Nacional UNESCO. O Perfil dos professores brasileiros: o que fazem, o que pensam, o que almejam. São Paulo: Moderna, 2004.

SAFFIOTI, H. I. B. Violência de Gênero no Brasil Atual. Estudos Feministas. UFSC. Ano 2. Out/1994. Estudos Feministas. Disponível em: <https://www.jstor.org/stable/ 243271 90?eq=1>. Acessado em: 28 maio 2021.

SAFFIOTI, H. I. B. Violência de gênero: lugar da práxis na construção da subjetividade. Revista Lutas Sociais, São Paulo, n. 2, 1997.

SAFFIOTI, H. I. B. Gênero, patriarcado, violência. São Paulo: Editora Fundação Perseu Abramo, 2004

SANTOS, Lucíola Licínio de Castro Paixão. Dimensões pedagógicas e políticas da formação contínua. in: VEIGA, Ilma Passos Alencastro. (org.). Caminhos da profissionalização do magistério. Campinas: Papirus, 1998.

SCOTT, Joan. Gênero: uma categoria útil de análise histórica. Educação \& Realidade. Porto Alegre, vol. 20, $\mathrm{n}^{\circ}$ 2, jul./dez. 1995. Disponível em: <https://seer.ufrgs.br/index.php/educacaoerealidade/article/view/71721>. Acessado em: 28 maio 2021.

SCHÖN, D. O profissional reflexivo: Como os profissionais pensam na ação. Londres: Temple Smith. 1983.

SILVA, Lilian de S.; LASTÓRIA, Luiz A. C. N. Educação e Diversidade Sexual. RIBH. Bauru, v. 7, n. 1, p. 279-293, Jan/jun., 2019. Disponível em: <https://www3.faac.unesp.br/ridh/index.php/ridh/article/view/671>. Acessado em: 28 maio 2021.

TARDIF, M. Saberes profissionais dos professores e conhecimentos universitários elementos para uma epistemologia da prática profissional dos professores e suas consequências em relação à formação para o magistério. Revista Brasileira de Educação, ANPED, São Paulo, n. 13, jan./abr. 2000. Disponível em: <http://www.ergonomia.ufpr.br/Metodologia/RBDE13_05_MAURICE_TARDIF.pdf >. Acessado em: 28 maio 2021.

\section{NOTAS}

\footnotetext{
${ }^{i}$ Adotou-se neste trabalho o termo homofobia para designar formas de preconceito e discriminação contra toda a população LGBTI.

ii De acordo com o relatório STATE-SPONSORED HOMOPHOBIA 2019, da Associação Internacional de Lésbicas, Gays, Bissexuais, Transexuais e Intersexuais (ILGA), seis países punem a homossexualidade com a pena de morte: Arábia Saudita, Irã, Iêmen, Sudão, Nigéria e Somália. Além disso, um homossexual pode ser condenado
} 
à morte na Mauritânia, nos Emirados Árabes Unidos, no Catar, no Paquistão e no Afeganistão. Disponível em https://ilga.org/downloads/ILGA_State_Sponsored_Homophobia_2019.pdf. Acessado dia 26 maio 2021

iii Disponível em: https://direito.mppr.mp.br/arquivos/File/RelatorioViolenciaHomofobicaBR2013.pdf. Acessado em 20 mar. 2021

${ }^{\text {iv }}$ Estamos tratando como marco legal o Estatuto da juventude considere jovens de 14 a 29 anos, embora a OMS Organização Mundial da Saúde que considera jovem de 15 a 24 anos. Destacamos que o marco legal não abarca a existência, na sociedade, das diferentes juventudes, que são constituídas pela classe, identidade de gênero, orientação sexual, grupo étnico racial, entre outros aspectos.

${ }^{v}$ Entrevista realizada em 02 dez. 2015.

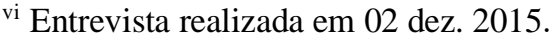

vii Entrevista realizada em 02 nov. 2015.

viii Performances de gênero são "ficções sociais prevalentes, coactivas, sedimentadas [que geram] um conjunto de estilos corporais que aparecem como uma organização natural [...] dos corpos em sexos, em uma relação binária e complementar" (BENTO, 2004, s.p.). Vide: BUTLER, 1998, 1999, 2002: 323-339; 2003: 48, 59, 168, $192-201$.

ix Disponível em: https://grupogaydabahia.files.wordpress.com/2020/03/relatorio-2017.pdf. Acessado dia 20 fev. 2021. 